Part of Journal of Research of the National Bureau of Standards, Volume 21, October 1938

\title{
HEAT AND FREE ENERGY OF FORMATION OF CARBON DIOXIDE, AND OF THE TRANSITION BETWEEN GRAPH- ITE AND DIAMOND
}

\author{
By Frederick D. Rossini and Ralph S. Jessup
}

\section{ABSTRACT}

There are reviewed the existing data on the entropies of oxygen, carbon dioxide, graphite, and diamond, and those on the heats of combustion of natural and artificial graphite and of diamond, including the results recently obtained in a joint investigation by the National Bureau of Standards and the Coal Research Laboratory of the Carnegie Institute of Technology. The new thermochemical data are combined with values of the entropies to obtain values for the heat and free energy of formation of carbon dioxide, and for the transition between graphite and diamond.

For $\mathrm{C}(\mathrm{c}$, graphite $)+\mathrm{O}_{2}(\mathrm{~g})=\mathrm{CO}_{2}(\mathrm{~g})$, at $25^{\circ} \mathrm{C}$, per mole, $\Delta H^{\circ}=-393,355$ \pm 46 NBS international joules, or $-94,030 \pm 11$ calories, and $\Delta F^{\circ}=-394,228$ \pm 58 NBS international joules, or $-94,239 \pm 14$ calories.

For $\mathrm{C}$ (c, graphite $)=\mathrm{C}$ (c, diamond), at $25^{\circ} \mathrm{C}$ and 1 atmosphere, $\Delta H=1,899$ \pm 124 joules, or $454 \pm 30$ calories, and $\Delta F=2,872 \pm 129$ joules, or $686 \pm 31$ calories. For this transition, the following equation is derived, with some approximations, for the range $T=273^{\circ}$ to $1,400^{\circ} \mathrm{K}$, and $P=0$ to 20,000 atmospheres: $\Delta F=541.82+$ $6700 / T+1.17662 T \log T-2.43723 T-0.000221 T^{2}-\left[0.045660+0.91236 \times 10^{-6} T\right.$ $\left.-0.7830 \times 10^{-10} T^{2}-0.3623 \times 10^{-12} T^{3}\right] P+0.19 \times 10^{-6} P^{2}$ calories per mole. (In all of the foregoing values, conversion from the NBS international joule to the conventional calorie is made with the factor $1 / 4.1833$. )

\section{CONTENTS}

I. Introduction

II. Review of the data on the heats of combustion of graphite and diamond.

1. Graphite

2. Diamond

III. Review of the data on the entropies of oxygen, carbon dioxide, graphite, and diamond _.

IV. Selected "best" values for the heat, entropy, and free energy of formation of carbon dioxide.

V. Heat, entropy, and free energy of the transition between graphite and diamond.

VI. Conclusion

VII. References

\section{INTRODUCTION}

From a review made several years ago on the thermochemistry of carbon $[1,2],{ }^{1}$ it appeared that there were several forms of graphite, none of which were very reproducible [3, 4]. As a result of that review,

\footnotetext{
1 Figures in brackets indicate the literature references at the end of this paper.
} 
Bichowsky and Rossini [2], for their table of the heats of formation of the chemical substances, selected diamond as the standard state for carbon, because it seemed to be the only truly reproducible form of solid carbon. However, the experimental data recently obtained in a joint investigation by the Coal Research Laboratory, of the Carnegie Institute of Technology, and the National Bureau of Standards, and reported in the preceding papers by Dewey and Harper [5] and Jessup [6], throw an entirely new light upon the thermochemistry of carbon. These new data make necessary a reselection of the standard state for carbon, and a revision of the present accepted values for the heat and the free energy of formation of carbon dioxide (from oxygen and graphite or diamond) and of the transition between graphite and diamond.

Because the heats of formation of most organic compounds containing carbon and hydrogen, or carbon, hydrogen, and oxygen, are derived from values for the heats of combustion of the organic compound and for the heats of formation of water and carbon dioxide, it is desirable to have accurate values for these two latter constants. ${ }^{2}$ In this connection, two points should be noted: (1) In the calculation, from values of heats of formation, of the heats of all those reactions in which neither of the elements hydrogen or carbon appears among the reactants or the products, the values actually assigned to represent the heats of formation of water and carbon dioxide are not important since they cancel out in the calculation; and (2) in calculating, from the values of heats of formation, the heat of a reaction in which solid carbon is one of the reactants or products, it is important to use the proper value for the heat of formation of the given solid carbon, the value being zero if the given form of carbon is that of the selected standard state.

The purpose of the present report is to select frc $m$ the new data a "best" value for the heat of formation of carbon dioxide (from oxygen and graphite or diamond) and for the heat of transition between graphite and diamond, and to combine these values with the best existing values for the entropies of carbon dioxide, oxygen, graphite, and diamond to obtain values for the free energy of formation of carbon dioxide and for the transition between graphite and diamond.

\section{REVIEW OF THE DATA ON THE HEATS OF COMBUSTION OF GRAPHITE AND DIAMOND}

\section{GRAPHITE}

Prior to 1938, data on the heat of combustion of graphite (see reference [2]) were reported by Grassi [11], Andrews [12], Favre and Silbermann [13], Berthelot and Petit [14], Mixter [15], Roth and Wallasch [3], Roth and Naeser [4], and Plummer [16]. With the exception of the three last-named investigations, all of this earlier work may be considered to be of historical interest only. On samples degassed in vacuo at $1,000^{\circ} \mathrm{C}$, Plummer [16] reported very high values. In this connection, Dewey and Harper [5] found it necessary to place a liquid-air trap between the vacuum system and the sample, in order to avoid having adsorption of oil-pump vapors by the graphite and consequent increase (as much as 0.85 percent) in the observed heat of combustion.

2 For a more extended discussion of the assembly of a table of heats of formation, see pages $233-234$ of reference [7], pages 1424-1425 of reference [8], and pages 9-16 of reference [2]. For the accepted "best" value for the heat of formation of water, see references $[9,10$, and 61$]$. 
In 1934, Rossini [1] recalculated the data of Roth and his coworkers on what they reported to be " $\beta$ " graphite, making the Washburn [17] reduction to 1 atmosphere and taking 1 mole of carbon to be $12.007 \mathrm{~g}$. Correcting the calculated value to the 1938 atomic weight of carbon, $12.010[19]$, there is obtained for the heat of the reaction

$$
\begin{aligned}
& \mathrm{C}(\mathrm{c}, \text { graphite })+\mathrm{O}_{2}(\mathrm{~g})=\mathrm{CO}_{2}(\mathrm{~g}) . \\
& \Delta H_{298 \cdot 16}=-94,220 \pm 80 \mathrm{cal} / \mathrm{mole}^{4}
\end{aligned}
$$

for " $\beta$ " graphite, at a pressure of 1 atmosphere. This value represents data obtained by Roth and his coworkers on samples of artificial graphite from different sources, including Acheson, Hochofen I, Hochofen II, Roheisen, and Spiegeleisen, and on samples of naturagraphite from different sources, including Ceylon I, Alibert, BayerWald, and Ticonderoga I.

Calculations made in a similar manner on the data reported by Roth and coworkers [3, 4], for what they termed " $\alpha$ " graphite, yield for the heat of formation of carbon dioxide according to reaction 1 ,

$$
\Delta H_{298.16}=-93,920 \pm 100 \mathrm{cal} / \mathrm{mole}
$$

from " $\alpha$ " graphite, at a pressure of 1 atmosphere. These data were obtained on three different samples of natural graphite, Pargas, Ceylon II, and Ticonderoga II.

On still another sample of graphite, which may be labelled intermediate, Roth and his coworkers reported data which lead to

$$
\Delta H_{298.16}=-94,110 \pm 100 \mathrm{cal} / \mathrm{mole}
$$

for the heat of reaction 1 at a pressure of 1 atmosphere. Roth suggested that this "intermediate" graphite might be a mixture of the " $\alpha$ " and " $\beta$ " forms, or even possibly a third form of graphite. These data were obtained on a sample of natural graphite, Ticonderoga III.

The different purifying treatments to which Roth and his coworkers subjected the various samples of graphite included on different samples, the following:

(1) On " $\beta$ " graphite.-(a) No treatment; (b) treatment successively with hydrochloric acid, hydrofluoric acid, a mixture of hydrochloric and hydrofluoric acids, and hydrochloric acid; and (c) treatment successively with hydrofluoric acid, hydrochloric acid, chlorine, and "red heat."

(2) On " $\alpha$ " graphite.-(a) No treatment; (b) treatment with fused sodium and potassium carbonates, and (c) treatment with hydrochloric acid.

(3) On "intermediate" graphite.-(a) No treatment; (b) treatment with hydrochloric acid; (c) treatment successively with aqua regia and hydrofluoric acid, and (d) treatment successively with hydrochloric acid, nitric acid, and hydrofluoric acid.

3 Roth and his coworkers determined the amount of reaction from the mass of sample placed in the crucible in the bomb less the mass of solid material remaining in the bomb after the combustion. In 1934, the atomic weight of carbon was given in the international table as 12.00 [18].

"See footnote 12 concerning the unit of energy. In the equations, the symbol "c" is an abbreviation for the word crystalline. 
In connection with the above samples, Roth and his coworkers found little correlation between the method of treatment and the result obtained for the heat of combustion. On a sample of Kahlbaum's Siberian graphite, however, Roth and Wallasch [3] reported the following data:

\begin{tabular}{|c|c|c|}
\hline Treatment & $\begin{array}{l}\text { Ash content } \\
\text { (percent by } \\
\text { weight) }\end{array}$ & $\begin{array}{l}\text { Heat of } \\
\text { combustion } \\
\text { (calories per } \\
\text { gram) }\end{array}$ \\
\hline $\begin{array}{l}\text { None } \\
\text { Hydrochloric acid, chlorine } \\
\text { Hydrofluoric acid, hydrochloric acid, chlorine } \\
\text { Hydrofluoric acid, nitric acid } \\
\text { Hydrofluoric acid, hydrochloric acid, chlorine... }\end{array}$ & $\begin{array}{r}>4 \\
\text { About } 3 \\
0.7 \\
.5 \\
.1\end{array}$ & $\begin{array}{l}7,685 \\
7,765 \\
7,810 \\
7,820 \\
7,820\end{array}$ \\
\hline
\end{tabular}

Concerning these results, Roth and Wallasch [3] stated:

* * * that the value obtained for the heat of combustion increased with decrease in the ash content; that this correlation might be due, in part, to the fact that the impurity may have been converted to a fine dust or volatilized during the combustion and minutely distributed throughout the bomb; and that, as a result, the amount of ash determined after the combustion would be low, yielding a high value for the amount of carbon burned and a low value for the heat of combustion per gram of carbon.

In his review of the data in 1934, one of the writers (Rossini) wrote the following [1]:

The existing data on the heat of formation of carbon dioxide may therefore be said to be quite unsatisfactory, and an accurate determination of this fundamental thermal constant is urgently needed. Any new determination of the heat of formation of carbon dioxide carried out by combustion of carbon in a bomb calorimeter should provide (a) for the accurate specification of the conditions of the bomb process in order that the Washburn correction may be made accurately, and (b) for the accurate determination of the amount of the reaction, preferably from the mass of carbon dioxide formed, in order to make insignificant the uncertainty in the value of the atomic weight of carbon and to eliminate the effect of the possible presence of incombustible impurities in the samples of carbon.

The new work on the thermochemistry of carbon [5,6] fulfills the foregoing requirements, and therefore serves to provide a value for the heat of formation of carbon dioxide that appears to be as accurate as it is possible to determine with present-day apparatus.

In table 1 is given a summary of the new results obtained by Dewey and Harper [5] and Jessup [6], on two samples of very pure artificial graphite of "spectroscopic" grade and samples of natural graphite from four different sources, Ceylon, Buckingham, Baffin Island, and Ticonderoga. The details of these experiments are given in the two papers cited [5,6]. Of this new work, it is important here to note the following:

1. The samples of natural graphite burned by Dewey and Harper were treated only by grinding, discarding the material not passing a 150 -mesh screen, and heating the remainder in vacuo for 6 hours at $225^{\circ} \mathrm{C}$. When so prepared, the samples of Buckingham, Baffin Island, and Ticonderoga graphite yielded values substantially identical with those of two samples of artificial graphite, in spite of the fact that these three samples of natural graphite contained, respectively, $0.25,1.7$, and 0.38 percent of ash, as compared with 0.00 percent of ash for the two samples of artificial graphite. On the other hand, the 
sample of Ceylon graphite, which contained 2.3 percent of ash, gave a value about 0.15 percent lower. From this, it appears that the foreign material contained in the samples of Buckingham, Baffin Island, and Ticonderoga graphite was substantially inert in these combustion experiments, where the amount of reaction (see page 494) was determined from the mass of carbon dioxide formed, while the foreign material in the sample of Ceylon graphite was significantly not inert.

TABLE 1.-Summary of the new data of Dewey and Harper and of Jessup on the heat of combustion of graphite, according to the reaction, $\mathrm{C}$ (c, graphite) $+\mathrm{O}_{2}(g)=$ $\mathrm{CO}_{2}(\mathrm{~g})$, at $25^{\circ} \mathrm{C}$ and a pressure of 1 atmosphere

\begin{tabular}{|c|c|c|c|c|c|}
\hline $\begin{array}{l}\text { Sample of } \\
\text { graphite }\end{array}$ & Treatment & $\begin{array}{c}\text { Ash } \\
\text { (percent } \\
\text { by } \\
\text { weight) }\end{array}$ & $\begin{array}{l}\text { Num- } \\
\text { ber of } \\
\text { experi- } \\
\text { ments }\end{array}$ & $\begin{array}{c}\text { Mean value } \\
\text { of }-\Delta H \\
\text { international } \\
\text { joules per } \\
\text { mole }\end{array}$ & Investigators \\
\hline $\begin{array}{l}\text { Ceylon } \\
\text { Buckingham...-. } \\
\text { Baffin Island...- } \\
\text { Ticonderoga...- } \\
\text { Artificial No.0.-- } \\
\text { Artificial No.1.-- }\end{array}$ & $\begin{array}{l}\text { Heating to } 225^{\circ} \mathrm{C} \text {, in vacuum } \\
\text { None do }\end{array}$ & $\begin{array}{l}2.3 \\
0.25 \\
1.7 \\
0.38 \\
.00 \\
.00\end{array}$ & $\begin{array}{l}4 \\
4 \\
4 \\
5 \\
4 \\
4\end{array}$ & $\begin{array}{c}(392,770 \pm 100) \\
393,360 \pm 130 \\
393,380 \pm 250 \\
393,330 \pm 110 \\
393,400 \pm 170 \\
393,260 \pm 150\end{array}$ & $\begin{array}{l}\text { Dewey and Harper[5]. } \\
\text { Do. } \\
\text { Do. } \\
\text { Do. } \\
\text { Do. } \\
\text { Do. }\end{array}$ \\
\hline \multicolumn{4}{|c|}{$\begin{array}{l}\text { Mean value of all the last } 21 \text { individual experiments above } \\
\text { (excluding those on Ceylon). }\end{array}$} & $393,350 \pm 110$ & Dewey and Harper [5]. \\
\hline  & Neating to $1,750^{\circ} \mathrm{C}$, in & $\begin{array}{l}1.50 \\
0.06\end{array}$ & $\begin{array}{l}6 \\
4\end{array}$ & $\begin{array}{c}(392,457 \pm 75) \\
393,405 \pm 75\end{array}$ & $\begin{array}{l}\text { Jessup }[6] \\
\text { Do. }\end{array}$ \\
\hline Do_ & $\begin{array}{l}\text { vacuum. } \\
\text { Treatment with } \mathrm{HCl} \text { and }\end{array}$ & .02 & 4 & $393,397 \pm 103$ & Do. \\
\hline Do..... & Treatment with $\mathrm{HCl}$ and & $\ngtr .02$ & 4 & $393,327 \pm 126$ & Do. \\
\hline Buckingham...- & Heating to $1,820^{\circ} \mathrm{C}$, in & .006 & 3 & $393,313 \pm 59$ & Do. \\
\hline $\begin{array}{l}\text { Artificial No. 1.- } \\
\text { Artificial No. 2.- }\end{array}$ & None-10.-1. & .00 & $\begin{array}{l}6 \\
3\end{array}$ & $\begin{array}{l}393,452 \pm 63 \\
393,441 \pm 99\end{array}$ & $\begin{array}{l}\text { Do. } \\
\text { Do. }\end{array}$ \\
\hline \multicolumn{4}{|c|}{$\begin{array}{l}\text { Mean value of all the last } 24 \text { individual experiments above } \\
\text { (excluding those on untreated Ceylon). }\end{array}$} & $393,396 \pm 51$ & Jessup [6]. \\
\hline
\end{tabular}

2. On identical samples of graphite burned both by Dewey and Harper and by Jessup, namely, untreated Buckingham, untreated Ceylon, and the two samples of artificial graphite, substantially the same respective values of the heats of combustion were obtained in the two investigations - the value of $-\Delta H$ for reaction 1 , at $25^{\circ} \mathrm{C}$ and 1 atmosphere, in NBS international joules per mole, being in the range 393,260 to 393,452 for all except the Ceylon graphite, which gave values in the range 392,457 to 392,770 .

3 . The foreign material in the Ceylon graphite can be largely removed, and the remainder made substantially inert, either by heating. the sample in vacuo to about $1,800^{\circ} \mathrm{C}$ or by treating it at room temperature with aqueous hydrochloric and hydrofluoric acids.

4. No significant change occurs in the energy content when a sample of Ceylon graphite, which has been chemically purified at temperatures below $200^{\circ}$ to $300^{\circ} \mathrm{C}$, is subsequently heated in vacuo to $1,820^{\circ} \mathrm{C}$.

These new data show that the energy content of 1 mole of carbon in the form of graphite is the same, within the narrow limits of the 
modern accurate measurements, for pure artificial graphite and for the natural graphites of Ceylon, Ticonderoga, Buckingham, and Baffin Island. From the fact that this energy content is the same for the man-made samples of graphite as for those produced by nature in widely scattered places on the earth, it may be concluded that, with respect to energy content, graphite is a thermodynamically reproducible form of carbon.

Taking the two mean values of all the final individual experiments performed by Dewey and Harper and by Jessup, and weighting the two mean values inversely as the squares of their assigned uncertainties, there is obtained for the heat of reaction 1 , for graphite, at $25^{\circ} \mathrm{C}$ and 1 atmosphere,

$$
\Delta H_{298.16}=-393,388 \pm 46 \text { NBS int. } \mathrm{j} / \text { mole. }
$$

This value gives the heat of combustion of graphite in oxygen to form carbon dioxide when each of the substances is at an actual pressure of 1 atmosphere. On correcting the gases, oxygen and carbon dioxide, to the hypothetical thermodynamic standard state ${ }^{5}$ of unit fugacity (of 1 atmosphere), there is obtained for reaction 1

$$
\Delta H^{\mathrm{o}}{ }_{298.16}=-393,355 \pm 46 \mathrm{NBS} \text { int. } \mathrm{j} / \mathrm{mole}^{\mathrm{s}}{ }^{\mathrm{s}}
$$

or in terms of the defined calorie, this is

$$
\Delta H^{\circ}{ }_{298.16}=-94,030 \pm 11 \mathrm{cal} / \mathrm{mole}^{7}
$$

It is interesting to note that the values computed from the data of Roth and his coworkers on " $\alpha$ " graphite, as given by eq 3 , and on the "intermediate" graphite, as given by eq 4, are in accord with the above value given by eq 7 , within the assigned limits of uncertainty, while the value computed for " $\beta$ " graphite, as given by eq 2 , differs from the value given by eq 7 by more than the combined uncertainties of the two values.

The question remains whether or not other forms of graphite exist. There is some evidence on this point in data on the density of purified samples of graphite. Values of the density of graphite reported by various observers are given in table 2 . The data of Le Chatelier and Wologdine [20] were obtained on samples of both artificial and natural graphite from various sources. The purification treatment, involving both physical and chemical means, consisted in the following: heating to a dull red heat; treating with nitric acid; treating with fused potassium hydroxide; and, after appropriate washing and drying, subjecting to a pressure of $5,000 \mathrm{~kg} / \mathrm{cm}^{2}$ to remove air. It is seen from table 2 that the densities of all the purified samples of Le Chatelier and Wologdine are in the range 2.255 to 2.264 , although the values for the unpurified samples range from 1.62 to 2.66 .

Arsem [63] investigated samples of petroleum coke, coal coke, retort carbon, and lampblack, which materials are known to be far from pure carbon, containing varying amounts of different impurities, the most important of which is hydrogen. Arsem heated these samples to about $3,000^{\circ} \mathrm{C}$ (not in vacuo) and obtained values of density for the resulting

\footnotetext{
$\checkmark$ The heat content of a gas in the hypothetical thermodynamic standard state is the same as that of the real gas at zero pressure at the same temperature (see reference [50]). For $\mathrm{O}_{2}(\mathrm{~g})$ and $\mathrm{CO}_{2}(\mathrm{~g})$ at $25^{\circ} \mathrm{C}$, the value of $H^{P-1}-H^{P-0}$ is calculated to be -8.4 and $-41 \mathrm{j} / \mathrm{mole}$, respectively.

6 The superseript zero placed on a thermodynamic symbol indicates that all the substances involved are $\mathrm{n}$ their thermodynamic standard states.

7 See footnote 12 , page 501 .
} 
materials ranging from 2.080 to 2.265 . Arsem stated that all the materials which resembled graphite after the heat treatment had densities in the range 2.25 to 2.265 , and expressed the opinion that the samples of lower density had not been converted into graphite. In the opinion of the present writers it is possible that, for those samples having the lower densities, the impurities in the original samples may not all have been removed in the short time of heating (15 minutes) at atmospheric pressure. For this reason only the values 2.250 to 2.265 are given in table 2 as the values obtained by Arsem for the density of graphite.

TABLE 2.-Summary of the values of the density of graphite reported by various observers

\begin{tabular}{|c|c|c|c|c|c|}
\hline \multirow{2}{*}{ Observer } & \multirow{2}{*}{ Year } & \multirow{2}{*}{ Designation of graphite } & \multicolumn{2}{|c|}{ Values of density reported } & \multirow{2}{*}{$\begin{array}{l}\text { Tem- } \\
\text { pera- } \\
\text { ture of } \\
\text { meas- } \\
\text { ure- } \\
\text { ment }\end{array}$} \\
\hline & & & $\begin{array}{l}\text { Before puri- } \\
\text { fication }\end{array}$ & $\begin{array}{l}\text { After purifi- } \\
\text { cation }\end{array}$ & \\
\hline $\begin{array}{l}\text { LeChatelier and Wologdine } \\
\text { [20]. }\end{array}$ & 1908 & $\left\{\begin{array}{l}\text { Acheson } \\
\text { Ceylon } \\
\text { Omenask } \\
\text { Fonte- } \\
\text { Australia- } \\
\text { Mugrau } \\
\text { Scharzbach } \\
\text { Commerce }\end{array}\right.$ & $\begin{array}{c}\mathrm{g} / \mathrm{cm}^{3} \\
1.62 \text { to } 2.05 \\
2.25 \\
2.06 \\
2.246 \\
2.66 \\
2.44 \\
2.36 \\
2.375\end{array}$ & $\begin{aligned} & g / \mathrm{cm}^{3} \\
& 2.255 \\
& 2.255 \\
& 2.255 \\
& 2.262 \\
& 2.255 \\
& 2.256 \\
& 2.255 \\
& 2.264\end{aligned}$ & $\begin{array}{l}{ }^{\circ} C \\
14 \text { to } 18 \\
14 \text { to } 18 \\
14 \text { to } 18 \\
14 \text { to } 18 \\
14 \text { to } 18 \\
14 \text { to } 18 \\
14 \text { to } 18 \\
14 \text { to } 18\end{array}$ \\
\hline $\begin{array}{l}\text { Cohen and Olie [21] } \\
\text { Arsem [63] }\end{array}$ & 1910 & Artificial & & & \\
\hline Arsem [63] & 1911 & $\begin{array}{l}\text { Artificial } \\
\text { (" } \beta \text { " (6 samples) }\end{array}$ & & $\begin{array}{l}\text { 2. } 250 \text { to } 2.265 \\
\text { 2. } 210 \text { to } 2.229\end{array}$ & 18 \\
\hline Roth and coworkers $[3,4] \ldots$ & $\begin{array}{c}1913 \\
\text { to } \\
1925\end{array}$ & $\left\{\begin{array}{l}\text { “ } \beta \text { ", (2 samples) } \\
\text { " } a \text { " (4 samples) } \\
\text { "Intermediate" (1 sample) }\end{array}\right.$ & & $\begin{array}{r}\text { 2. } 261 \text { to } 2.265 \\
\text { 2. } 252 \text { to } 2.260 \\
\text { 2. } 255\end{array}$ & $\begin{array}{l}18 \\
18 \\
18\end{array}$ \\
\hline $\begin{array}{l}\text { Ryschkewitsch and Köster- } \\
\text { mann [22]. }\end{array}$ & 1924 & Artificial & & 2.232 & \\
\hline $\begin{array}{l}\text { Bernal [67] } \\
\text { Hassel and Mark [68] }\end{array}$ & $\begin{array}{l}1924 \\
1924\end{array}$ & $\begin{array}{c}\text { Artificial and natural..- } \\
\text { do }\end{array}$ & & $\begin{array}{l}\text { 2. } 236 \pm 0.050 \\
\text { 2. } 228 \pm 0.035\end{array}$ & 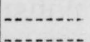 \\
\hline Ott $[69]$ & 1928 & Natural_........... & & $2.195 \pm 0.055$ & 10 \\
\hline $\begin{array}{l}\text { Hofmann and W } \\
\text { Trzebiatowski } 6\end{array}$ & 1936 & Artificial and natural & 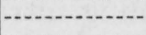 & 2. $268 \pm 0.008$ & \\
\hline $\begin{array}{l}\text { Trzebiatowsk1 } \\
\text { Lamb and Ohl [23] }\end{array}$ & $\begin{array}{l}1938 \\
1938\end{array}$ & Artificial (2 samples) & & $\begin{array}{r} \pm 0.001 \\
2.269\end{array}$ & 19 to 20 \\
\hline
\end{tabular}

The value reported by Cohen and Olie [21] was for a sample of artificial graphite which was prepared in the electric arc, contained no measurable amount of ash, had been dried to constant weight at $120^{\circ}$ to $130^{\circ} \mathrm{C}$, and subjected to a pressure of 5,000 to 10,000 atmospheres.

The value reported by Ryschkewitsch and Köstermann [22] is the mean of values ranging from 2.230 to 2.235 obtained on globules of graphite which had been fused in the electric arc under a pressure of $12 \mathrm{~mm}$ of mercury. These authors refer to the work of LeChatelier and Wologdine and express the opinion that density values obtained with samples of graphite which had been subjected to high pressure would be too high. The present writers are of the opinion that it is more likely that samples of graphite which were prepared in the manner described by Ryschkewitsch and Köstermann would contain voids as a result of bubbles forming in the fused graphite at the low pressure.

From X-ray diffraction data, Bernal [67], Hassel and Mark [68], and Ott [69] reported the following values for the lattice constants of graphite, $a$ and $c$, respectively, in $\mathrm{A}\left(10^{-8} \mathrm{~cm}\right)$ : Bernal, $2.45 \pm 0.03$, 
$6.82 \pm 0.04 ;$ Hassel and Mark, 2.46, 6.79; and Ott, 2.48, 6.78. The values of density of graphite attributed to these authors in Table 2 were calculated by the present writers from the above data, using the values 12.010 for the atomic weight of carbon, and $6.06 \times 10^{23}$ for Avogadro's number.

Hofmann and Wilm [52] reported for the lattice constant of sodium chloride the value $5.626 \pm 0.001 \mathrm{~A}$, and for the lattice constants of graphite the values $a=2.455 \pm 0.002 \mathrm{~A}, c=6.69 \pm 0.01 \mathrm{~A}$. The present writers have calculated the value for the density of graphite attributed to Hofmann and Wilm in table 2 from the above data, using the value $2.1642 \pm 0.0001$ reported by $\mathrm{Tu}$ [66] for the density of rock salt.

Trzebiatowski [65] reported for the lattice constant of diamond the value $a=3.55957 \mathrm{~A}$, and for the lattice constants of graphite the values $a=2.4561 \mathrm{~A}, c=6.6950 \mathrm{~A}$, all at about $20^{\circ} \mathrm{C}$. The value for the density of graphite of Trzebiatowski in table 2 was calculated by the present writers from the above data, together with the value 3.513 reported by Adams for the density of diamond at $25^{\circ} \mathrm{C}$.

The values of density reported by Roth and his coworkers $[3,4]$ were obtained on the samples of graphite, the heats of combustion of which they determined. Concerning these data, Roth and Naeser [4] stated that with two exceptions, a high density corresponds to a low heat of combustion, and, further, concerning the data of LeChatelier and Wologdine [20], that a pressure of $5,000 \mathrm{~kg} / \mathrm{cm}^{2}$ may have changed " $\beta$ " graphite into " $\alpha$ " graphite.

Burns and Hulett [64] made density measurements on three samples of natural graphite and one sample of artificial graphite. Their density values differ considerably from those of most other observers, and have not been included in table 2 , as representative of pure macrocrystalline graphite, for the following reasons: (1) Some of the samples contained considerable amounts of impurities which may have caused appreciable errors in the measured densities; and (2) the samples which had been treated with fuming nitric acid, and subsequently heated, suffered a large increase in volume, and the resulting material may also have contained graphitic oxides as impurities.

Lamb and Ohl [23] obtained the same value for the density of each of two samples of graphite, one of which was an artificial graphite having a carbon content of $96.19 \pm 0.04$ percent, the remainder being oxide of iron; while the other sample was prepared by evaporation of silicon from silicon carbide, and had a carbon content of $99.92 \pm 0.04$ percent.

It is seen from table 2 that all of the density values for purified graphite are in accord with the value $2.260 \pm 0.010$, within the respective limits of uncertainty, with the following exceptions:

1. One sample of artificial graphite of high purity, which had been subjected to a pressure of 5,000 to 10,000 atmospheres, was observed by Cohen and Olie [21] to have a density of 2.216 .

2 . Six samples of " $\beta$ " graphite were observed by Roth and coworkers $[3,4]$ to have densities ranging from 2.210 to 2.229 .

3. The density values reported by Burns and Hulett have not been included by the present writers for the reasons given above. 
4. Several samples of the same graphite which had been fused in the electric arc were observed by Ryschkewitsch and Köstermann [22] to have densities in the range 2.230 to 2.235 .

As noted above, there is some reason for suspecting that the results of the last-mentioned measurements may have been too low on account of voids in the samples. In regard to the results of Roth and his coworkers, the fact that the "intermediate" graphite and two of the " $\beta$ " graphites had densities as high as those of the " $\alpha$ " graphites throws some doubt upon the correlation of density with heat of combustion, as suggested by Roth and Naeser [4]. Also, the fact that the " $\beta$ " graphites observed by Roth and his coworkers to have low densities had not been subjected to pressure, as were the samples investigated by LeChatelier and Wologdine [20], raises the question whether these low values of density might not have been caused by voids in the graphite. There remains, therefore, only one low density value, that of Cohen and Olie, for which no plausible explanation has been found.

After considering both the data on heats of combustion and on densities, the present writers are of the opinion that, while there may possibly be more than one form of crystalline graphite, the existing data do not establish this as a fact; and, further, it is their belief that the great variations reported in the values of different properties of samples of artificial and natural graphites may be due entirely to the presence of impurities or voids in the samples subjected to measurement, and in the case of heats of combustion to the method of determining the amount of reaction. As has already been stated in an earlier paper [7], it is the burden of every investigator to analyze carefully the chemical compounds which are being subjected to measurement, both the reactants and the products if a reaction is involved, in order to establish beyond reasonable doubt the purity of the compounds, or reaction, being studied. As is the case for any pure chemical substances, the preparation of a "pure" sample of graphite, which is to be subjected to measurement of a given chemical or physical property, should involve such an amount of purifying treatment as will substantially remove all impurities which are significant in amount and not "inert" in the measurement which is to be made. Until more definite information to the contrary is obtained, it would seem desirable to assume the existence of only one form of graphite; namely, that which is represented by the samples of the artificial and natural graphites described by Dewey and Harper [5] and Jessup [6]. Since these samples were selected quite at random, it would be expected that any other form of graphite, if it exists, must occur in limited abundance. Furthermore, it should also be established that a new form, if found, is a definite and reproducible one.

\section{DIAMOND}

Prior to 1938, data on the heat of combustion of diamond were reported by Andrews [12], Favre and Silbermann [13], Berthelot and Petit [14], Roth and Wallasch [3], and Roth and Naeser [4]. With the exception of the work of Roth and his coworkers, all of these investigations may be considered to be of historical interest only.

In 1934, Rossini [1] recalculated the data of Roth and coworkers $[3,4]$ on diamond, making the Washburn [17] reduction to 1 atmos- 
phere and taking 1 mole of carbon to be $12.007 \mathrm{~g}^{8}{ }^{8}$ Correcting to the 1938 atomic weight of carbon 12.010 [19], and making the Washburn correction on the basis of the data obtained by Roth and Naeser with their microbomb [4], the writers calculate for the heat of the reaction

$$
\begin{gathered}
\mathrm{C}(\mathrm{c}, \text { diamond })+\mathrm{O}_{2}(\mathrm{~g})=\mathrm{CO}_{2}(\mathrm{~g}) \\
\Delta H_{29813}=-94,410 \pm 100 \mathrm{cal} / \mathrm{mole}
\end{gathered}
$$

at a pressure of 1 atmosphere.

TABLE 3.-Summary of the data obtained by Jessup [6] on the heat of combustion of diamond

[C (c, diamond) $\left.+\mathrm{O}_{2}(\mathrm{~g})=\mathrm{CO}_{2}(\mathrm{~g})\right]$

\begin{tabular}{c|r|r|r}
\hline Sample No. & $\begin{array}{c}\text { Average par- } \\
\text { ticle diame- } \\
\text { ter } 1\end{array}$ & $\begin{array}{c}\text { Ash on } \\
\text { combus- } \\
\text { tion }\end{array}$ & $\begin{array}{c}\Delta H \text { at } 25^{\circ} \mathrm{C} \text { and } \\
\text { a pressure of } 1 \\
\text { atmosphere }\end{array}$ \\
\hline & $\begin{array}{r}10^{-4} \mathrm{~cm} \\
2.5\end{array}$ & $\begin{array}{r}\text { Percent by } \\
\text { weight } \\
0.05\end{array}$ & $\begin{array}{r}\text { NBS int. j/mole } \\
-395,771 \pm 150 \\
-395,287 \pm 115\end{array}$ \\
\hline
\end{tabular}

${ }^{1}$ See Jessup [6] for method of determination.

A summary of the new data on diamond obtained by Jessup [6] is given in table 3 . The two values given in this table differ by 484 $\mathrm{j} /$ mole, or 0.12 percent, which difference is nearly twice the sum of the calculated uncertainties of the two values. ${ }^{9}$ As pointed out in the paper by Jessup [6], the difference between the values of the heat of combustion of diamond is in the direction to be expected from the relative sizes of the particles in the two samples, but the difference is greater than would be expected from the sizes actually measured. Although the difference in the two values in table 3 is small, it is definitely greater than the experimental uncertainty, and appears to be attributable to some phenomena (probably surface) associated with the nearly microcrystalline form of sample 1 , since the specific surface, in square centimeters per gram, for this sample is about 250 times greater than that for the coarser fraction of sample 2 (see Jessup [6]). Sample 2 may be considered representative of macrocrystalline diamond. ${ }^{10}$

It appears, therefore, that the "best" value for the heat of formation of carbon dioxide, from macrocrystalline diamond and oxygen, according to reaction 8 , at $25^{\circ} \mathrm{C}$ and a pressure of 1 atmosphere, may be taken as

$$
\Delta H_{298.16}=-395,287 \pm 115 \text { NBS int. } \mathrm{j} / \text { mole. }
$$

\footnotetext{
8 See footnote 3
}

The uncertainties given in table 3 include the uncertainties of the calibration experiments and of the value used for the heat of combustion of benzoic acid, as well as the uncertainty of the combustion experiments on the diamond. Since the calorimetric system was identical in the experiments on the two samples of diamond, the uncertainty to be used in the direct comparison of the two values should be that calculated only from the precision of the combustion experiments on diamond. These latter are \pm 120 and $\pm 64 \mathrm{j} / \mathrm{mole}$ for samples 1 and 2, respectively. The values in table 3 differ by 2.6 times the sum of these latter precision uncertainties.

${ }_{10} \mathrm{~A}$ discussion of the significance, with respect to the energy content, of the new and rare form of diamond recently reported by Robertson, Fox, and Martin [49] is given in the preceding paper by Jessup. 
On correcting the gases oxygen and carbon dioxide to the thermodynamic standard state, ${ }^{11}$ there is obtained for reaction 8

$$
\Delta H^{\circ}{ }_{298 \cdot 16}=-395,254 \pm 115 \mathrm{NBS} \text { int. } \mathrm{j} / \text { mole, or }-94,484 \pm 28
$$

It is interesting to note that the value calculated from the work. of Roth and his coworkers, as given by eq 9 , is in accord with the above value from the work of Jessup within the assigned limits of uncertainty.

\section{REVIEW OF THE DATA ON THE ENTROPIES OF OXYGEN, CARBON DIOXIDE, GRAPHITE, AND DIAMOND}

The entropy of gaseous oxygen at $25^{\circ} \mathrm{C}$ has been accurately determined from statistical calculations, utilizing spectroscopic and other molecular data, by Giauque and Johnston [24] and Johnston and Walker [25]. (See also Lewis and von Elbe [26].) These statistically calculated values are practically identical with one another, and are confirmed by calculations made according to the third law of thermodynamics, utilizing calorimetric data on heat capacities, and heats of transition, fusion, and vaporization, down to about $-261^{\circ} \mathrm{C}$, by Giauque and Johnston [24]. (See also Clusius [27] and Eucken [28].) For the entropy of 1 gram-mole of $\mathrm{O}_{2}$ (gas), in the standard state (fugacity equal to 1 atmosphere) at $25^{\circ} \mathrm{C}$, the various values expressed in calories per degree-mole, are: ${ }^{12}$

Giauque and Johnston [24], statistical $49.03 \pm 0.02$

Johnston and Walker [25], statistical $49.019 \pm .010$

Giauque and Johnston [24], third law $49.09 \pm .10$

The "best" value for $S^{\circ}{ }_{298.16}$ for $\mathrm{O}_{2}$ (g) may be taken as 205.061 $\pm 0.040 \mathrm{NBS}$ int. $\mathrm{j} / \mathrm{deg}$-mole, or $49.019 \pm 0.010 \mathrm{cal} / \mathrm{deg}$-mole. ${ }^{13}$

The entropy of gaseous carbon dioxide at $25^{\circ} \mathrm{C}$ has been accurately calculated statistically by Badger and Woo [32], Gordon [33], Kassel [34], Kelley [35], and Giauque and Egan [36]. (See also Gordon and Barnes [37].) These values are in accord with one another, and are confirmed by the accurate value obtained by Giauque and Egan [36] according to the third law from calorimetric data down to about $-258^{\circ} \mathrm{C}$. For the entropy of 1 gram-mole of $\mathrm{CO}_{2}$ (gas) in the standard state of unit fugacity at $25^{\circ} \mathrm{C}$, the various values, in calories per degree-mole, are: ${ }^{14}$
Badger and Woo [32], statistical
Gordon [33], statistical $51.07 \pm 0.03$
Kassel [34], statistical $51.09 \pm .02$
$51.084 \pm .010$


Giauque and Egan [36], third law
$51.07 \pm .02$
$51.11 \pm .13$

\footnotetext{
11 See footnote 5

${ }_{12}$ The calorie used in this paper is the defined calorie, taken as equal to 4.1833 int. $j$ [7]. In terms of this unit, the gas content $R$ has the value $1.9869 \pm 0.0003 \mathrm{cal} / \mathrm{deg} / \mathrm{mole}$, when the absolute temperature of the ice point is taken as $273.16 \pm 0.02^{\circ} \mathrm{K}$ [29], $1 \mathrm{NBS}$ int. $\mathrm{j}$ is taken as 1.0003 absolute $\mathrm{j}[30]$, and $(P V)_{0} \mathrm{C}^{=}(R T)$ $0^{\circ} \mathrm{C}$ is taken as equal to $2,271.11 \pm 0.24$ absolute $\mathrm{J} / \mathrm{mole}$ [31]. Within the assigned limits, the numerical values reported by the various investigators have been appropriately converted. The uncertainties assigned here to the values of entropy are relative, because only values of $\Delta S$ are actually used in the present calculations.

${ }_{13}$ The superscript zero on the symbol $S$ (for entropy) indicates the hypothetical thermodynamic state of the gas with fugacity equal to 1 atmosphere.

14 See footnotes 12 and 13 .
} $94848-38-9$ 
The "best" value for $S^{\circ}{ }_{298.16}$ for $\mathrm{CO}_{2}(\mathrm{~g})$ may be taken as 213.700 $\pm 0.040 \mathrm{NBS}$ int. $\mathrm{j} / \mathrm{deg}$-mole, or $51.084 \pm 0.010 \mathrm{cal} / \mathrm{deg}-\mathrm{mole}$.

Calorimetric measurements, down to low temperatures, of the heat capacity of crystalline carbon in the form of graphite have been made by Nernst [38], and Jacobs and Parks [39]. Koref [40] made several isolated measurements. (See also Weber [41].) Jacobs and Parks [39] combined their data in the range from about $90^{\circ}$ to $300^{\circ} \mathrm{K}$ with those of Nernst [38] in the range from about $30^{\circ}$ to $90^{\circ} \mathrm{K}$, and, from the third law, deduced a value for the entropy at $25^{\circ} \mathrm{C}$. Their result, corrected to a value of 12.010 for the atomic weight of carbon [19], and expressed in terms of the units used in the present report,,$^{15}$ becomes $5.712 \pm 0.100 \mathrm{NBS}$ int. $\mathrm{j} /$ deg-mole, or $1.365 \pm 0.025$ cal/deg-mole. This value, which may be taken as the present "best" one for $S_{298.16}^{\circ}$ for C (c, graphite) is in accord, within the respective limits of uncertainty, with values calculated from the data of Nernst [38], by Lewis and Gibson [42], Rodebush and Rodebush [43], Clusius and Woitinek [44], Terebesi [45], and Kelley [46]. (See also Kelley [47].)

Measurements, down to low temperatures, of the heat capacity of crystalline carbon in the form of diamond have been made by Nernst [38] and Pitzer [48], with some isolated measurements by Weber [41] and Robertson, Fox, and Martin [49]. The recent measurements of Pitzer [48], with which all of the older data are in substantial accord within their respective limits of uncertainty, cover the range from $70^{\circ}$ to $288^{\circ} \mathrm{K}$, and yield for the entropy of 1 mole $(12.010 \mathrm{~g})$ of diamond, at $25^{\circ} \mathrm{C}$, the value $2.448 \pm 0.040 \mathrm{NBS}$ int. $\mathrm{j} / \mathrm{deg}$-mole, or $0.585 \pm 0.010 \mathrm{cal} / \mathrm{deg}-\mathrm{mole}$. The foregoing value is in substantial accord with those calculated from the then existing data by Lewis and Gibson [42], Rodebush and Rodebush [43], Clusius and Woitinek [44], and Kelley [46].

\section{SELECTED "BEST" VALUES FOR THE HEAT, ENTROPY, AND FREE ENERGY OF FORMATION OF CARBON DIOXIDE}

The "best" value for the heat of formation of carbon dioxide from oxygen and graphite, with each substance in its thermodynamic standard state, according to the reaction

$$
\mathrm{C} \text { (c, graphite) }+\mathrm{O}_{2}(\mathrm{~g})=\mathrm{CO}_{2}(\mathrm{~g})
$$

is that given by eq 6 and 7 ; namely,

or

$$
\Delta H^{\circ}{ }_{298.16}=-393,355 \pm 46 \mathrm{NBS} \text { int. } \mathrm{j} / \mathrm{mole},
$$

$$
\Delta H^{\circ}{ }_{298.16}=-94,030 \pm 11 \mathrm{cal} / \mathrm{mole} .
$$

From the selected "best" values (see pages 501-502) for the entropies of graphite, oxygen, and carbon dioxide, the change in entropy for the formation of carbon dioxide according to reaction 1 is

$\Delta S_{298.16}^{\circ}=2.927 \pm 0.121 \mathrm{j} / \mathrm{deg}-\mathrm{mole}$, or $0.700 \pm 0.029 \mathrm{cal} / \mathrm{deg}-\mathrm{mole}$.

\footnotetext{
15 See footnote 12
} 
Utilizing the thermodynamic relation

$$
\Delta F=\Delta H-T \Delta S,
$$

and taking $0^{\circ} \mathrm{C}=273.16^{\circ} \mathrm{K}$, the change in free energy at $25^{\circ} \mathrm{C}$ for reaction 1 is calculated to be

$\Delta F^{\circ}{ }_{298.16}=-394,228 \pm 58 \mathrm{NBS}$ int. $\mathrm{j} / \mathrm{mole}$, or $-94,239 \pm 14 \mathrm{cal} / \mathrm{mole}$.

In a similar manner, for the formation of carbon dioxide from diamond and oxygen, according to the reaction

$$
\mathrm{C}(\mathrm{c} \text {, diamond })+\mathrm{O}_{2}(\mathrm{~g})=\mathrm{CO}_{2}(\mathrm{~g})
$$

the following values are calculated:

$\Delta H^{\circ}{ }_{298.16}=-395,254 \pm 115 \mathrm{NBS}$ int. j/mole, or $-94,484 \pm 28 \mathrm{cal} / \mathrm{mole}$

$\Delta S^{\circ}{ }_{298.16}=6.191 \pm 0.073 \mathrm{j} / \mathrm{deg}$-mole, or $1.480 \pm 0.017 \mathrm{cal} / \mathrm{deg}$-mole (16) $\Delta F^{\circ}{ }_{298.16}=-397,100 \pm 116 \mathrm{NBS}$ int. j/mole, or $-94,925 \pm 28 \mathrm{cal} / \mathrm{mole}$.

From the data of Johnston and Walker [25] on oxygen and of Kassel [34] on carbon dioxide, there are obtained, for the gas in the thermodynamic standard state, the following values for the heat content at $25^{\circ} \mathrm{C}$ referred to the absolute zero of temperature, $\mathrm{H}_{298.16}^{\circ}-\mathrm{H}^{\circ}{ }_{0}: \mathrm{O}_{2}$ (g), $8652.3 \pm 3.0$ NBS int. $\mathrm{j} / \mathrm{mole}$, or $2068.3 \pm 0.7 \mathrm{cal} / \mathrm{mole} ; \mathrm{CO}_{2}(\mathrm{~g})$ $9369.3 \pm 4.0 \mathrm{NBS}$ int. $\mathrm{j} / \mathrm{mole}$, or $2239.7 \pm 1.0 \mathrm{cal} / \mathrm{mole}$. From a plot of the data on the heat capacity of graphite by Jacobs and Parks [39] from $90^{\circ}$ to $300^{\circ} \mathrm{K}$, and by Nernst [38] from $30^{\circ}$ to $90^{\circ} \mathrm{K}$, with an appropriate extrapolation to $0^{\circ} \mathrm{K}$, the present writers obtain for C (c, graphite), $H^{\circ}{ }_{298.16}-H^{\circ}{ }_{0}=1053.8 \pm 12.5 \mathrm{NBS}$ int. $\mathrm{j} / \mathrm{mole}$, or $251.9 \pm 3.0 \mathrm{cal} / \mathrm{mole}$. Combining these three values for $\mathrm{H}^{\circ}{ }_{298.16}-H^{\circ}{ }_{0}$ with eq 6 and 7 , there is obtained for the heat of reaction at the absolute zero of temperature for

$$
\mathrm{C} \text { (c, graphite) }+\mathrm{O}_{2}(\mathrm{~g})=\mathrm{CO}_{2}(\mathrm{~g})
$$

$\Delta H^{\circ}{ }_{0}=-393,018 \pm 48 \mathrm{NBS}$ int. $\mathrm{j} / \mathrm{mole}$, or $-93,949 \pm 11 \mathrm{cal} / \mathrm{mole}$

From a plot of the data on the heat capacity of diamond by Pitzer [48] from $70^{\circ}$ to $300^{\circ} \mathrm{K}$, with an appropriate extrapolation to $0^{\circ} \mathrm{K}$, the present writers obtain for $\mathrm{C}$ (c, diamond),

$H^{\circ}{ }_{298.16}-H^{\circ}{ }_{0}=536.3 \pm 2.5$ int. $\mathrm{j} / \mathrm{mole}$, or $128.2 \pm 0.6 \mathrm{cal} / \mathrm{mole}$.

Combining this value and those given above for oxygen and carbon dioxide with eq 15 , there is obtained for the heat of reaction at the absolute zero of temperature for

$$
\mathrm{C}(\mathrm{c} \text {, diamond })+\mathrm{O}_{2}(\mathrm{~g})=\mathrm{CO}_{2}(\mathrm{~g})
$$

$\Delta H^{\circ}{ }_{0}=-395,435 \pm 115 \mathrm{NBS}$ int. $\mathrm{j} / \mathrm{mole}$, or $-94,527 \pm 28 \mathrm{cal} / \mathrm{mole}$. 


\section{HEAT, ENTROPY, AND FREE ENERGY OF THE TRANSITION BETWEEN GRAPHITE AND DIAMOND}

From the thermodynamic values given by eq 6 and 7 , the formula 13 , and the values of the entropies of graphite and diamond (pages 501 and 502), there may be calculated for the transition of crystalline carbon from the form of graphite to that of diamond,

$$
\mathrm{C}(\mathrm{c}, \text { graphite })=\mathrm{C}(\mathrm{c}, \text { diamond }) \text {, }
$$

the following thermodynamic values for a pressure of 1 atmosphere:

$$
\Delta H^{\circ}{ }_{298 \cdot 16}=1,899 \pm 124 \mathrm{j} / \mathrm{mole} \text {, or } 454 \pm 30 \mathrm{cal} / \mathrm{mole} \text {. }
$$

$\Delta S^{\circ}{ }_{298 \cdot 16}=-3.264 \pm 0.113 \mathrm{j} / \mathrm{deg}-\mathrm{mole}$, or $-0.780 \pm 0.027 \mathrm{cal} / \mathrm{deg}-\mathrm{mole}$. (22)

$$
\Delta F^{\circ}{ }_{298 \cdot 16}=2,872 \pm 129 \mathrm{j} / \mathrm{mole} \text {, or } 686 \pm 31 \mathrm{cal} / \mathrm{mole} \text {. }
$$

Utilizing the values for $H^{\circ}{ }_{298 \cdot 13}-H^{\circ}{ }_{0}$ already given for graphite and diamond (see page 503) together with eq 21, there is obtained for the heat and free energy of the transition

$$
\mathrm{C}(\mathrm{c}, \text { graphite })=\mathrm{C}(\mathrm{c}, \text { diamond })
$$

at the absolute zero of temperature.

$$
\Delta H^{\circ}{ }_{0}=\Delta F^{\circ}{ }_{0}=2,417 \pm 125 \mathrm{j} / \mathrm{mole} \text {, or } 578 \pm 30 \mathrm{cal} / \mathrm{mole} \text {. }
$$

From a review of the available data on the heat capacities of graphite and diamond, Kelley [51] deduced the following equations to give the heat capacities as a function of the absolute temperature $T$ :

For C (c, graphite), in the range from $273^{\circ}$ to $1,373^{\circ} \mathrm{K}$, with an estimated accuracy of about 2 percent.

$$
C_{P}=2.673+0.002617 T-116900 / T^{2} \mathrm{cal} / \mathrm{deg}-\mathrm{mole} \text {. }
$$

For $\mathrm{C}$ (c, diamond), in the range from $273^{\circ}$ to $1,313^{\circ} \mathrm{K}$, with an estimated accuracy of about 3 percent,

$$
C_{P}=2.162+0.003059 T-130300 / T^{2} \mathrm{cal} / \mathrm{deg}-\mathrm{mole} .
$$

Combination of eq $21,23,25$, and 26 with the two thermodynamic relations,

$$
\begin{gathered}
\partial(\Delta F / T) / \partial T=-\Delta H / T^{2}, \\
\partial(\Delta H) / \partial T=\Delta C_{p} .
\end{gathered}
$$

yields for the transition of graphite into diamond,

$$
\mathrm{C}(\mathrm{c}, \text { graphite })=\mathrm{C}(\mathrm{c}, \text { diamond }) \text {, }
$$

the following relation between the free-energy change at 1 atmosphere and the absolute temperature, for the range $273^{\circ} \mathrm{K}$ to about $1,400^{\circ}$ $\mathrm{K}$ :

$$
\Delta F=541.77+6700 / T+1.17662 T \log T-2.43723 T-0.000221 T^{2}
$$

The numerical constants in eq 29 are carried out to the number of figures indicated only for the sake of internal consistency. Actually, 
the least uncertainty in $\Delta F$ is estimated to be $\pm 31 \mathrm{cal} / \mathrm{mole}$, at $25^{\circ}$ $\mathrm{C}$ or $298.16^{\circ} \mathrm{K}$. At $1,400^{\circ} \mathrm{K}$, the uncertainty in $\Delta F$ is somewhat greater because of the additional uncertainty contributed by the constants in the heat-capacity eq 25 and 26 . As indicated above, eq 28 is applicable only in the range from $273^{\circ}$ to about $1,400 \mathrm{~K}$.

Values of the free-energy change for reaction 20 at higher pressures can be calculated from the corresponding values at atmospheric pressure by means of the relation

$$
\partial\left(\Delta F^{\prime}\right) / \partial P=\Delta V,
$$

using published data on the densities, thermal expansions, and compressibilities of diamond and graphite to evaluate $\Delta V$ for the reaction as a function of pressure and temperature.

Measurements of the density of diamond were made by Adams [53], Cohen and Olie [21], Roth and coworkers [3, 4], Robertson, Fox, and Martin [49], and Tu [66]. The values derived from the data of the various investigators are given in table 4 . The measurements of Adams, and of Cohen and Olie were made on relatively large samples (10 g or more) and should therefore be quite reliable. The values reported ${ }^{16}$ by Robertson, Fox, and Martin were obtained by measuring the difference of the weights in air and in water of single diamonds having masses ranging from 0.05 to $0.9 \mathrm{~g}$ each. It would be expected that the values obtained with the smaller diamonds would be less reliable than those obtained with the larger ones, and for this reason the present writers, in computing the average value attributed to Robertson, Fox, and Martin in table 4, have taken only their values for the five diamonds weighing $0.5 \mathrm{~g}$ or more. These five values range from 3.507 to $3.520 \mathrm{~g} / \mathrm{cm}^{3}$. The mean of all the 14 ralues reported by Robertson, Fox, and Martin is 3.509 $\mathrm{g} / \mathrm{cm}^{3}$. The first of the two values of the density of diamond attributed to Tu [66] in table 4 is the mean of values obtained by measuring the density of solutions in which the diamonds just floated. The second value attributed to Tu was calculated by the present writers from Tu's measured density of calcite $(2.71003 \pm 0.00005 \mathrm{~g} / \mathrm{ml})$, together with the mean values, obtained from Tu's X-ray measurements, for the grating constant of calcite, $3.02940 \pm 0.00005 \mathrm{~A}$, the unit volume of calcite $(1.09602 \pm 0.00001)$, and the grating constant of diamond, $3.55961 \pm 0.00005 \mathrm{~A}$.

TABLE 4.-Summary of values reported for the density of diamond

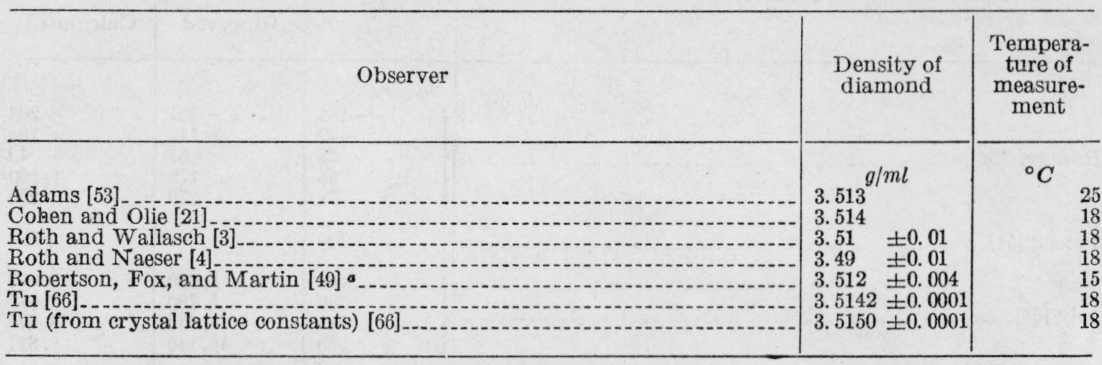

a See text on page 505.

${ }_{16}$ The values of $d_{15^{15}}$ given by Robertson, Fox, and Martin have been converted to $\mathrm{g} / \mathrm{cm}^{3}$ by the present writers. 
Data on the thermal expansion of diamond have been reported by Fizeau [54], Joly [55], Röntgen [56], and Cohen and Olie [21]. The data of Cohen and Olie are apparently in error, as they indicate a negative coefficient of expansion in the range $-38^{\circ}$ to $0^{\circ} \mathrm{C}$, and a positive coefficient in the range $-163^{\circ}$ to $0^{\circ} \mathrm{C}$; neither of these coefficients is consistent with the data of the other observers. Using the expansion data of Fizeau, Joly, and Röntgen, and the value of the density of diamond reported by Adams, the present writers have derived the following empirical equation representing the molal volume of diamond as a function of temperature at atmospheric pressure

$$
\begin{gathered}
V(\text { diamond })=3.41812-6.2146 \times 10^{-6} T+2.32517 \times 10^{-8} \\
T^{2}+14.958 \times 10^{-12} T^{3} \pm 0.0030 \mathrm{~cm}^{3} / \mathrm{mole} .
\end{gathered}
$$

In table 5 , values of $\left(V_{t}-V_{0}\right) / V_{0}$ calculated from eq 31 are compared with the corresponding experimental values, $\left(V_{0}\right.$ is the volume at $0^{\circ}$ $\mathrm{C}$ and $V_{t}$ the volume at $\left.t^{\circ} \mathrm{C}\right)$. The agreement is well within the uncertainty of the absolute values of the molal volumes, but not quite within the precision of the expansion data at temperatures up to $100^{\circ} \mathrm{C}$.

The only published measurements of the compressibility of diamond are those of Adams [53], who obtained the value $(0.16 \pm 0.02) \times 10^{-6}$ per bar, or $\left(0.16_{2} \pm 0.02\right) \times 10^{-6}$ per atmosphere, at $25^{\circ} \mathrm{C}$, for the range from 2,000 to 10,000 bars. As the compressibility enters as a very small term in the calculation of the free-energy change for the transition of graphite to diamond, the temperature coefficient of the compressibility of diamond is assumed to be negligible for the present calculations. Combining this value of compressibility with eq 31 , and neglecting terms which amount to less than $10^{-4} \mathrm{~cm}^{3} /$ mole at $T=1,000^{\circ} \mathrm{K}$ and $P=20,000$ atmospheres, there is obtained the following expression for the molal volume of diamond as a function of the pressure $P$ in atmospheres and the temperature $T$ in ${ }^{\circ} \mathrm{K}$ :

$$
\begin{gathered}
V(\text { diamond })=3.41812-6.2146 \times 10^{-6} T+2.32517 \times 10^{-8} \\
T^{2}+14.958 \times 10^{-12} T^{3}-0.55 \times 10^{-6} \mathrm{~cm}^{3} / \mathrm{mole} .
\end{gathered}
$$

\begin{tabular}{|c|c|c|c|}
\hline \multirow{2}{*}{ Observer } & \multirow{2}{*}{ Temperature, } & \multicolumn{2}{|c|}{ Value of $10^{6}\left(V_{t}-V_{0}\right) / V_{0}$} \\
\hline & & Observed & Calculated \\
\hline Röntgen [56] & $\begin{array}{r}{ }^{\circ} \mathrm{C} \\
-188 \\
-79 \\
23 \\
55 \\
78\end{array}$ & $\begin{array}{r}-201 \\
-142 \\
67 \\
179 \\
279\end{array}$ & $\begin{array}{r}-203 \\
-165 \\
72 \\
190 \\
290\end{array}$ \\
\hline Fizeau [54] & 100 & 396 & 396 \\
\hline Joly [55] $\ldots .$. & $\begin{array}{l}400 \\
580 \\
686 \\
750\end{array}$ & $\begin{array}{r}3,420 \\
5,790 \\
7,950 \\
10,140\end{array}$ & $\begin{array}{l}3,093 \\
6,017 \\
8,275 \\
9,847\end{array}$ \\
\hline
\end{tabular}

TABLE 5.-Comparison of observed values for $\left(V_{t}-V_{0}\right) / V_{0}$ for diamond with those calculated by equation 31 
The most extensive measurements of the thermal expansion of graphite were made by Hidnert and Sweeney [57], and by Hidnert [58], on artificial-graphite electrodes of various sizes. In the case of two of these electrodes, one 14 inches and the other 3 inches in diameter, measurements were made both in the direction parallel to the length of the electrode, and in a direction at right angles. For both of these electrodes the transverse coefficients of expansion were found to be consistently larger than the longitudinal coefficients. It is the opinion of the present writers that this difference between the longitudinal and transverse coefficients is the result of a partial orientation of the graphite crystals in such a manner that the basal planes of the crystals are on the average more nearly parallel to the axes of the electrodes than to the plane at right angles to the axis. Such an orientation might be caused, for example, by friction with the walls of the die through which the "green" electrodes are extruded when being formed. The assumption that the graphite crystals are oriented in the manner described above is consistent with the following facts: (1) The graphite electrodes have been observed $[57,58]$ to have a laminar structure, the laminae being parallel to the axes of the electrodes, and (2), in the expansion measurements of Hidnert and Sweeney [57], and of Hidnert [58], it was found that the electrode which had the larger longitudinal coefficient had the smaller transverse coefficient. This would be expected if the difference in the longitudinal and transverse coefficients is due to partial orientation of the crystals, and if the orientation is more nearly complete in one electrode than in the other.

The present writers have derived an equation to represent the volume expansion of graphite, making use of the data of Hidnert [58], in the following manner: The average values of the observed mean longitudinal linear coefficient of expansion, $\alpha_{l}$, were added to twice the corresponding average observed mean transverse linear coefficient of expansion, $\alpha_{t}$, to obtain the mean volume coefficient of expansion, $\alpha_{v}$, for both the 14-inch and the 3 -inch electrodes. The volume coefficients were then used to calculate the quantity $\left(V_{t}-V_{20}\right) / V_{20}$, where $V_{t}$ represents the volume at $t^{\circ} \mathrm{C}$ and $V_{20}$ that at $20^{\circ} \mathrm{C}$, for various temperatures from $20^{\circ}$ to $1,000^{\circ} \mathrm{C}$, for both electrodes. The corresponding values for the two electrodes were then averaged, and the average values of $\left(V_{t}-V_{20}\right) / V_{20}$ were used to derive the following equation:

$$
\left(V_{t}-V_{20}\right) / V_{20}=8.1274 \times 10^{-6}(t-20)+3.7671 \times 10^{-9}(t-20)^{2} .
$$

In table 6 are given the average values of the mean coefficients $\alpha_{l}$ and $\alpha_{t}$ for both the 3 -inch and the 14-inch electrodes; the corresponding mean volume coefficients, $\alpha_{v}$, calculated in the manner described above for each electrode; values of $\left(V_{t}-V_{20}\right) / V_{20}$ for each electrode, calculated from the corresponding values of $\alpha_{0}$; the means of these two sets of values of $\left(V_{t}-V_{20}\right) / V_{20}$; and values of $\left(V_{t}-V_{20}\right) / V_{20}$ calculated from eq 33. It is seen from table 6 that values of $V_{t} / V_{0}$ at $t=1,000^{\circ} \mathrm{C}$ calculated from the expansion coefficients for the two electrodes differ by about 0.3 percent, and that the values of $V_{t} / V_{0}$ calculated from eq 33 represent the means of the two sets of values of $V_{t} / V_{0}$ for the two electrodes within about 0.02 percent.

Measurements of the longitudinal thermal expansion of a $1 / 2$-inch graphite rod over the temperature range $0^{\circ}$ to $1,500^{\circ} \mathrm{C}$ have been 
reported by Day and Sosman [60]. Their data are in agreement with the measurements of Hidnert [58] on a 1-inch electrode, but as no measurements were made of the expansion in the transverse direction, the data of Day and Sosman were not considered in deriving eq 33. Eq 33 is consistent with measurements by Cohen and Olie [21] of the change in density of an artificial graphite between $18^{\circ}$ and $-38^{\circ} \mathrm{C}$, but is not consistent with their measurements of the change in density between $-38^{\circ} \mathrm{C}$ and $-163^{\circ} \mathrm{C}$.

TABLE 6.-Values calculated from the data on the thermal expansion of graphite reported by Hidnert and Sweeny [57] and Hidnert [58]

\begin{tabular}{|c|c|c|c|c|c|c|c|c|c|c|c|}
\hline \multirow{2}{*}{ Remarks } & \multirow{2}{*}{ Quantity } & \multicolumn{10}{|c|}{ Interval of temperature, ${ }^{\circ} \mathrm{C}$} \\
\hline & & $\begin{array}{c}20 \text { to } \\
100\end{array}$ & $\begin{array}{c}20 \text { to } \\
200\end{array}$ & $\begin{array}{c}20 \text { to } \\
300\end{array}$ & $\begin{array}{c}20 \text { to } \\
400\end{array}$ & $\begin{array}{c}20 \text { to } \\
500\end{array}$ & $\begin{array}{c}20 \text { to } \\
600\end{array}$ & $\begin{array}{c}20 \text { to } \\
700\end{array}$ & $\begin{array}{c}20 \text { to } \\
800\end{array}$ & $\begin{array}{c}20 \text { to } \\
900\end{array}$ & $\begin{array}{l}20 \text { to } \\
1,000\end{array}$ \\
\hline $\begin{array}{l}\text { From data on the } \\
\text { 14-inch electrode } \\
\text { of graphite..... }\end{array}$ & $\left\{\begin{array}{l}a_{l} \ldots \\
a_{t} \\
a_{0} \\
10^{6}\left(\bar{V}_{l}-V_{20}\right) / V_{20}\end{array}\right.$ & $\begin{array}{r}1.79 \\
2.69 \\
7.17 \\
574\end{array}$ & $\begin{array}{r}1.68 \\
2.80 \\
7.28 \\
1,310\end{array}$ & $\begin{array}{r}1.96 \\
3.05 \\
8.06 \\
2,257\end{array}$ & $\begin{array}{r}2.05 \\
3.27 \\
8.59 \\
3,264\end{array}$ & $\begin{array}{r}2.53 \\
3.60 \\
9.70 \\
4,656\end{array}$ & $\begin{array}{r}2.30 \\
3.46 \\
9.22 \\
5,348\end{array}$ & $\begin{array}{r}2.35 \\
3.30 \\
8.95 \\
6,086\end{array}$ & $\begin{array}{r}2.50 \\
3.60 \\
9.70 \\
7,566\end{array}$ & \begin{tabular}{|r}
2.62 \\
3.60 \\
9.82 \\
8,642
\end{tabular} & \begin{tabular}{r|r}
2 & 2.63 \\
0 & 3.77 \\
2 & 10.17 \\
2 & 9,967
\end{tabular} \\
\hline $\begin{array}{l}\text { From data on the } \\
\text { 3-inch electrode } \\
\text { of graphite.... }\end{array}$ & $\left\{\begin{array}{l}a_{l} \ldots \\
a_{t} \ldots \\
a_{p} \\
10^{0}\left(V_{t}-V_{20}\right) / V_{20}\end{array}\right.$ & $\begin{array}{r}1.10 \\
4.10 \\
9.30 \\
744\end{array}$ & $\begin{array}{r}1.32 \\
4.23 \\
9.78 \\
1,760\end{array}$ & $\begin{array}{r}1.51 \\
4.38 \\
10.27 \\
2,876\end{array}$ & $\begin{array}{r}1.72 \\
4.52 \\
10.76 \\
4,079\end{array}$ & 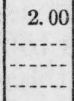 & $\begin{array}{r}2.05 \\
4.80 \\
11.65 \\
6,757\end{array}$ & $\begin{array}{r}2.08 \\
4.90 \\
11.88 \\
8,078\end{array}$ & \begin{tabular}{r|r|}
2.28 \\
5.20 \\
12.68 \\
9,890
\end{tabular} & \begin{tabular}{r|r}
2.31 \\
5.30 \\
12.91 \\
11,361
\end{tabular} & \begin{tabular}{r|r}
1 & 2.55 \\
0 & 5.40 \\
1 & 13.35 \\
1 & 13,083
\end{tabular} \\
\hline $\begin{array}{l}\text { A verage for the } \\
\text { two specimens.-- }\end{array}$ & $\left\{10^{6}\left(V_{t}-V_{20}\right) / V_{20}\right.$ & 659 & 1,535 & 2,566 & 3,671 & & 6,052 & 7,082 & 8,728 & 10,001 & 111,525 \\
\hline Calculated from eq & \} $10^{6}\left(V_{t}-V_{20}\right) /$ & 674 & 1,585 & 2,571 & 3,632 & & 5,981 & 7,269 & 8,631 & 10,069 & 911,583 \\
\hline
\end{tabular}

Data for the density of graphite have already been reviewed (see pages 496 and 499). Most of the published values of the density of graphite are in the range from 2.25 to $2.27 \mathrm{~g} / \mathrm{cm}^{3}$. As the "best" value for the density of graphite at $20^{\circ} \mathrm{C}$, the present writers select the value $2.260 \pm 0.010 \mathrm{~g} / \mathrm{cm}^{3}$.

The only published value for the compressibility of graphite is that of Richards [59], namely, $3.0 \times 10^{-6}$ per bar, or $3.0_{4} \times 10^{-6}$ per atmosphere, at $20^{\circ} \mathrm{C}$, over the range 1 to 500 bars. As the variation of compressibility of graphite with temperature and pressure is not known, the influence of these variables is assumed to be negligible for the present calculations.

Combining the above values of density and compressibility of graphite with eq 33, there is obtained the following equation representing the molal volume of graphite as a function of the pressure $P$ in atmospheres and the temperature $T$ in ${ }^{\circ} \mathrm{K}$ :

$$
\begin{gathered}
V(\text { graphite })=5.30322+31.453 \times 10^{-6} T+2.00190 \times 10^{-8} T^{2}-16.1 \\
\times 10^{-6} P \mathrm{~cm}^{3} / \mathrm{mole}^{2}
\end{gathered}
$$

Combining eq 32 and 34 , there is obtained the following equation giving the change in volume, $\Delta V$, for the transition,

$$
\mathrm{C}(\mathrm{c}, \text { graphite })=\mathrm{C}(\mathrm{c}, \text { diamond }),
$$

as a function of the pressure $P$ in atmospheres and the temperature $T$ in ${ }^{\circ} \mathrm{K}$ :

$$
\begin{gathered}
\Delta V=-1.8851-37.6676 \times 10^{-6} T+0.32327 \times 10^{-8} T^{2}+14.958 \times 10^{-12} T^{3} \\
+15.6 \times 10^{-6} P \mathrm{~cm}^{3} / \mathrm{mole}
\end{gathered}
$$


Combination of eq 30 and 35 , yields the following equation, with $\Delta F$ in calories per mole, $P$ in atmospheres, and $T$ in ${ }^{\circ} \mathrm{K}$ :

$$
\begin{gathered}
\partial\left(\Delta F^{\prime}\right) / \partial P=-0.045660-0.91236 \times 10^{-6} T+0.007830 \times 10^{-8} T^{2}+0.3623 \\
\times 10^{-12} T^{3}+0.38 \times 10^{-6} P .
\end{gathered}
$$

Integration of eq 36 at constant temperature between the limits of pressure of 1 atmosphere and $P$ atmospheres yields

$$
\begin{gathered}
\Delta F^{P}{ }_{T}=F^{P=1} T_{T}-\left[0.045660+0.91236 \times 10^{-6} T-0.007830 \times 10^{-8} T^{2}-0.3623\right. \\
\left.\times 10^{-12} T^{3}\right](P-1)+0.19 \times 10^{-6}\left(P^{2}-1\right) \mathrm{cal} / \mathrm{mole} .
\end{gathered}
$$

Combining eq 29 and 37 , there is obtained the following equation giving the free energy change for the transition of graphite to diamond (eq 20) as a function of the absolute temperature $T$ in ${ }^{\circ} \mathrm{K}$ and of the pressure $P$ in atmospheres:

$$
\begin{aligned}
& \Delta F=541.82+6700 / T+1.17662 T \log T-2.43723 T-0.000221 T^{2} \\
& -\left[0.045660+0.91236 \times 10^{-6} T-0.7830 \times 10^{-10} T^{2}-0.3623\right. \\
& \left.\times 10^{-12} T^{3}\right] P+0.19 \times 10^{-6} P^{2} \mathrm{cal} / \mathrm{mole} .
\end{aligned}
$$

Figure 1 shows a plot, for various pressures, of the free-energy change against the absolute temperature for the transition of graphite into diamond. The data for this plot for temperatures in the range $300^{\circ}$ to $1,400^{\circ} \mathrm{K}$ were calculated from eq 38 . The value of the free energy change for $T=0^{\circ} \mathrm{K}$ and $P=1$ atmosphere is that given on page 504. The values at $0^{\circ} \mathrm{K}$ for the other pressures were calculated from the value at one atmosphere by extrapolating the change in $\Delta F$ over the respective pressure ranges, which change was found to be very nearly independent of temperature in the range $300^{\circ}$ to $1,400^{\circ} \mathrm{K}$.

The curves of figure 1 indicate that below a pressure of about 13,000 atmospheres there is no temperature at which diamond is stable with respect to graphite. At $300^{\circ} \mathrm{K}$, it is calculated that a pressure of about 16,000 atmospheres is required to produce equilibrium between diamond and graphite, and at $470^{\circ} \mathrm{K}$, a pressure of about 20,000 atmospheres is required.

In regard to the range of pressure and temperature over which eq 38 is applicable, the following facts should be noted: (1) the first five terms in the equation were derived from specific-heat data which cover the range $273^{\circ}$ to $1,313^{\circ} \mathrm{K}$ for diamond, and $273^{\circ}$ to $1,373^{\circ} \mathrm{K}$ for graphite; (2) the coefficient of $P$ in eq 38 was obtained from values of density of graphite and diamond at atmospheric pressure, and data on thermal expansion which cover the range from $293^{\circ}$ to $1,273^{\circ} \mathrm{K}$ in the case of graphite, and from $85^{\circ}$ to $1,023^{\circ} \mathrm{K}$ in the case of diamond; and (3) the coefficient of $P^{2}$ in eq 38 was obtained from compressibility data on diamond at $298^{\circ} \mathrm{K}$ over a pressure range extending to 10,000 atmospheres, and from compressibility data on graphite at $293^{\circ} \mathrm{K}$ over a pressure range extending to 500 atmospheres. Hence the calculation from eq 38 of values of $\Delta F$ at $P=1$ atmosphere from $273^{\circ}$ to $1,400^{\circ} \mathrm{K}$ includes the uncertainty in the value of $\Delta F$ at $25^{\circ} \mathrm{C}$ and the uncertainty in the heat capacity eq 25 and 26 , and involves only a moderate extrapolation beyond the range of the experimental data. At pressures higher than about 500 atmospheres, 
in the neighborhood of room temperature, the calculation of $\Delta F$ from eq 38 involves extrapolation of the data on the compressibility of graphite. At all temperatures much above room temperature, errors may be introduced into the calculation of $\Delta F$ from eq 38 at pressures higher than atmospheric because the change of compressibility,

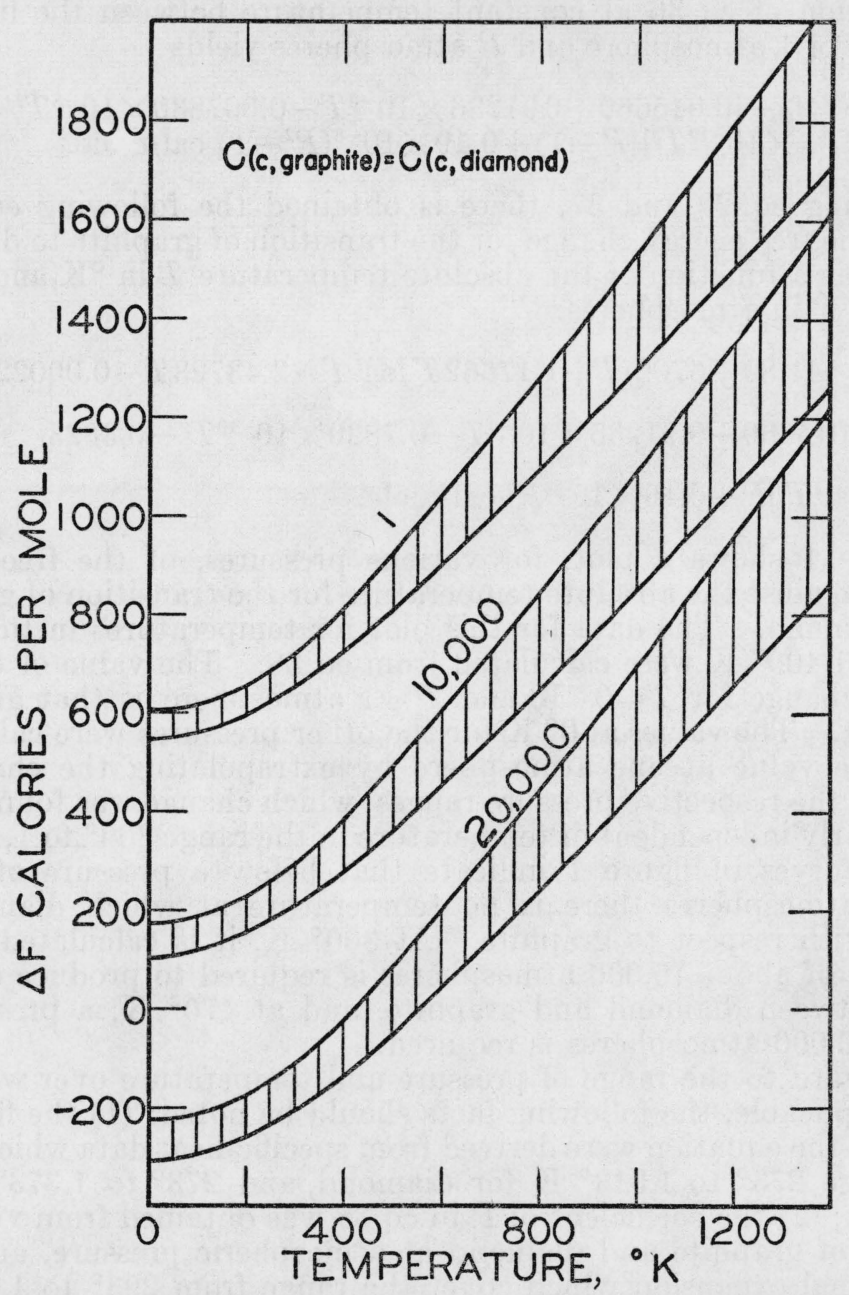

FIGURE 1.-Plot, for various pressures, of the free energy change against the absolute temperature, for the transition of graphite into diamond: $\mathrm{C}(c$, graphite $)=\mathrm{C}$ (c, diamond).

The scale of ordinates gives the free-energy change, $\Delta F$, in calories per mole, and the scale of abscissas gives the absolute temperature in degrees Kelvin. The number attached to each curve indicates the pressure in atmospheres. The width of each band is twice the estimated uncertainty.

chiefly of graphite, with temperature was neglected in deriving the equation. At temperatures above $1,023^{\circ} \mathrm{K}$, there is an additional uncertainty in the calculated values of $\Delta F$ at pressures above atmospheric, arising from extrapolation of the expansion data on diamond. The authors have considered these factors, together with the esti- 
mated uncertainties in the densities of graphite and diamond at room temperature, the uncertainty of \pm 31 cal given previously for the value of $\Delta F$ for the transition from graphite to diamond at $298^{\circ} \mathrm{K}$ and $P=1$ atmosphere, the uncertainty in the heat capacity eq 25 and 26 , and have estimated the uncertainty in values of $\Delta F$ calculated from eq 38 for $P=20,000$ atmospheres to be of the order of \pm 40 cal at $298^{\circ} \mathrm{K}$, and \pm 170 cal at $1,400^{\circ} \mathrm{K}$.

\section{CONCLUSION}

As a result of the work of Jessup [6] at the National Bureau of Standards and of Dewey and Harper [5] at the Coal Research Laboratory of the Carnegie Institute of Technology, it appears definitely established that a simple purification either (1) by treatment with aqueous hydrochloric and hydrofluoric acids at room temperature followed by washing and then drying in a vacuum at about $200^{\circ} \mathrm{C}$, or (2) by heating in vacuum to about $1,800^{\circ} \mathrm{C}$, suffices to produce a thermodynamically reproducible form of graphite, either from artificial or from natural graphite. It is recommended, therefore, that in compilations of values of the heats and free energies of formation of chemical compounds containing carbon, the standard reference state (see [2] and [7]) for carbon be that of graphite (as defined above) which is inexpensive and easily accessible, rather than the more expensive and more difficultly accessible diamond, which, several years ago, it appeared necessary to use as the standard reference state for carbon because of the then apparently variable properties of graphite [1, 2].

The thermodynamic values calculated in the present paper and offered as the present "best" ones for the respective reactions, are summarized in table 7 .

TABLE 7.-Summary of thermodynamic values

\begin{tabular}{|c|c|c|c|c|c|c|}
\hline \multirow[b]{2}{*}{ Reaction } & \multicolumn{2}{|c|}{$\Delta H^{\circ}{ }_{0}$} & \multicolumn{2}{|c|}{$\Delta H^{\circ}{ }_{208.16}$} & \multicolumn{2}{|c|}{$\Delta F^{\circ}{ }_{298 \cdot 16}$} \\
\hline & $\begin{array}{l}\text { NBS interna- } \\
\text { tional joules } \\
\text { per mole }\end{array}$ & $\begin{array}{l}\text { Calories a } \\
\text { per mole }\end{array}$ & $\begin{array}{l}\text { NBS interna- } \\
\text { tional joules } \\
\text { per mole }\end{array}$ & $\begin{array}{l}\text { Calories a } \\
\text { per mole }\end{array}$ & $\begin{array}{l}\text { NBS interna- } \\
\text { tional joules } \\
\text { per mole }\end{array}$ & $\begin{array}{l}\text { Calories }{ }^{a} \\
\text { per mole }\end{array}$ \\
\hline $\begin{array}{c}\mathrm{C}(\mathrm{c}, \text { graphite)+ } \\
\mathrm{O}_{2}(\mathrm{~g})=\mathrm{CO}_{2}(\mathrm{~g})- \\
\mathrm{C}(\mathrm{c}, \text { diamond } \\
\mathrm{O}_{2}(\mathrm{~g})=\mathrm{CO}_{2}(\mathrm{~g}) \\
\mathrm{C}(\mathrm{c}, \text { graphite })= \\
\mathrm{C}(\mathrm{c}, \text { diamond })\end{array}$ & $\begin{aligned}-393,018 & \pm 48 \\
-395,435 & \pm 115 \\
2,417 & \pm 125\end{aligned}$ & $\mid \begin{array}{r}-93,949 \pm 11 \\
-94,527 \pm 28 \\
578 \pm 30\end{array}$ & $\begin{array}{r}-393,355 \pm 46 \\
-395,254 \pm 115 \\
1,899 \pm 124\end{array}$ & $\begin{aligned}-94,030 & \pm 11 \\
-94,484 & \pm 28 \\
454 & \pm 30\end{aligned}$ & $\left\{\begin{aligned}-394,228 & \pm 58 \\
-397,100 & \pm 117 \\
2,872 & \pm 129\end{aligned}\right.$ & $\mid \begin{aligned}-94,239 & \pm 14 \\
-94,925 & \pm 28 \\
686 & \pm 31\end{aligned}$ \\
\hline
\end{tabular}

a See footnote 12 .

The authors gratefully acknowledge the benefits of discussions with H. H. Lowry, Director of the Coal Research Laboratory of the Carnegie Institute of Technology, and with G. E. F. Lundell, Chief of the Chemistry Division, and E. F. Mueller, Chief of the Heat Measurements Section, of this Bureau. 


\section{REFERENCES}

[1] F. D. Rossini, J. Research NBS 13, 21 (1934) RP692.

[2] F. R. Bichowsky and F. D. Rossini, The Thermochemistry of the Chemical Substances, Reinhold Publishing Corporation, New York, N. Y. (1936).

[3] W. A. Roth and H. Wallasch, Ber deut. chem. Ges. 46, 896 (1913); Z. Elektrochem. 21, 1 (1915).

[4] W. A. Roth and W. Naeser, Z. Elektrochem. 31, 461 (1925).

[5] P. H. Dewey and D. R. Harper, 3d, J. Research NBS 21, 457 (1938) RP1139.

[6] R. S. Jessup, J. Research NBS 21, 475 (1938) RP1140.

[7] F. D. Rossini, Chem. Revs. 18, 233 (1936).

[8] F. D. Rossini, Ind. Eng. Chem. 29, 1424 (1937).

[9] F. D. Rossini, BS J. Research 6, 1 (1931); \%, 329 (1931) RP343.

[10] Premier Rapport de la Commission Permanente de Thermochimie, Union Internationale de Chimie, Paris (1934).

[11] Grassi, J. pharm. chim. 8, 170 (1845).

[12] T. Andrews, Phil. Mag. [3] 32, 426 (1848).

[13] P. A. Favre and J. T. Silbermann, Ann. chim. phys. [3] 34, 357 (1852).

[14] M. Berthelot and Petit, Ann. chim. phys. [6] 18, 80 (1889); Compt. rend. 108, 1144 (1889).

[15] W. G. Mixter, Am. J. Sci: 19, 434 (1905).

[16] W. B. Plummer, Ind. Eng. Chem. 22, 630 (1930).

[17] E. W. Washburn, BS J. Research 10, 525 (1933) RP546.

[18] G. P. Baxter, M. Curie, O. Hönigschmid, P. LeBeau, and R. J. Meyer, J. Am. Chem. Soc. 56, 753 (1934).

[19] G. B. Baxter, O. Hönigschmid, and P. LeBeau, J. Am. Chem. Soc. 60, 737 (1938).

[20] H. LeChatelier and S. Wologdine, Compt. rend. 146, 49 (1908).

[21] E. Cohen and J. Olie, Jr., Z. physik. Chem. 71, 385 (1910).

[22] E. Ryschkewitsch and E. Köstermann, Z. Elektrochem. 30, 86 (1924).

[23] A. B. Lamb and E. N. Ohl, J. Am. Chem. Soc. 60, 1287 (1938).

[24] W. F. Giauque and H. L. Johnston, J. Am. Chem. Soc. 51, 2300 (1929).

[25] H. L. Johnston and M. K. Walker, J. Am. Chem. Soc. 55, $172(1933) ; 5 \%$, 682 (1935).

[26] B. Lewis and G. von Elbe, J. Am. Chem. Soc. 55, 511 (1933); 5\%, 1399 (1935).

[27] K. Clusius, Z. physik. Chem. [B] 3, 41 (1929).

[28] A. Eucken, Verhandl. deut. phys. Ges. 18, 4 (1916).

[29] Private communication from F. G. Brickwedde, member, for the National Bureau of Standards, of the Thermometric Committee of the International Institute of Refrigeration.

[30] H. L. Curtis and R. W. Curtis, BS J. Research 12, 665 (1934) RP685.

[31] R. T. Birge, Phys. Rev. Supplement 1, 1 (1929).

[32] R. M. Badger and S. C. Woo, J. Am. Chem. Soc. 54, 3523 (1932).

[33] A. R. Gordon, J. Chem. Phys. 1, 308 (1933).

[34] L. S. Kassel, J. Am. Chem. Soc. 56, 1838 (1934).

[35] K. K. Kelley, Bul. 384, U. S. Bureau of Mines (1935).

[36] W. F. Giauque and C. J. Egan, J. Chem. Phys. 5, 45 (1937).

[37] A. R. Gordon and C. Barnes, J. Phys. Chem. 36, 2292 (1932).

[38] W. Nernst, Ann. Physik 36, 395 (1911).

[39] C. J. Jacobs and G. S. Parks. J. Am. Chem. Soc. 56, 1513 (1934).

[40] F. Koref, Ann. Physik 36, 49 (1911).

[41] H. F. Weber, Phil. Mag. [4] 49, 161, 276 (1875).

[42] G. N. Lewis and G. E. Gibson, J. Am. Chem. Soc. 39, 2554 (1917).

[43] W. H. Rodebush and E. Rodebush, Int. Crit. Tables 5, 87 (McGraw-Hill Book Co., New York, N. Y., 1929).

[44] K. Clusius and Woitinek, Landolt-Börnstein-Roth-Scheel Tabellen, Second Supplement, part II, p. 1237 (Julius Springer, Berlin, 1931).

[45] Terebesi, Helv. Chim. Acta 1\%, 804 (1934).

[46] K. K. Kelley, Bul. 350, U. S. Bureau of Mines (1932).

[47] K. K. Kelley, Bul. 394, U. S. Bureau of Mines (1936).

[48] K. S. Pitzer, J. Chem. Phys. 6, 68 (1938).

[49] R. Robertson, J. J. Fox, and A. E. Martin, Phil. Proc. Roy. Soc. (London) [A] 15\%, 579 (1936); Trans. Roy. Soc. (London) [A] 232, 463 (1934).

[50] G. N. Lewis and M. Randall, Chemical Thermodynamics and the Free Energy of Chemical Substances. McGraw-Hill Book Co., New York, N. Y. (1923). 
[51] K. K. Kelley, Bul. 371, U. S. Bureau of Mines (1934).

[52] U. Hofman and D. Wilm, Z. Elektrochem. 42, 504 (1936).

[53] L. H. Adams, J. Wash. Acad. Sci. 11, 45 (1921).

[54] H. Fizeau, Pogg. Ann. Phys. Chem. 128, 583 (1868); 138, 26 (1869).

[55] J. Joly, Sci. Trans. Roy. Soc. Dublin [2] 6, 283 (1898).

[56] Röntgen, Sitzber. math-physik. Klasse bayer. Akad. Wiss. München 42, 381 (1912).

[57] P. Hidnert and W. T. Sweeney, Tech. Pap. BS 21, 223 (1927) T335.

[58] P. Hidnert, J. Research NBS 13, 37 (1934) RP693.

[59] T. W. Richards, J. Am. Chem. Soc. 3\%, 1643 (1915).

[60] A. L. Day and R. B. Sosman, Ind. Eng. Chem. 4, 490 (1912).

[61] F. D. Rossini, forthcoming paper in J. Research NBS.

[62] NBS Tech. News Bul. 246, p. 100 (1937).

[63] W. C. Arsem, Ind. Eng. Chem. 3, 799 (1911); Trans. Am. Electrochem. Soc. 20, 105 (1911).

[64] R. M. Burns and G. A. Hulett, J. Am. Chem. Soc. 45, 572 (1923).

[65] W. Trzebiatowski, Roczniki Chem. 17, 73 (1937).

[66] Y. Tu, Phys. Rev. 40, 662 (1932).

[67] J. Bernal, Proc. Roy. Soc. (London) 106, 750 (1924).

[68] O. Hassel and H. Mark, Z. Physik. 25, 317 (1924).

[69] H. Ott, Ann. Physik [4] 85, 81 (1928).

Washington, August 18, 1938. 